\title{
Epidural Hematoma: Report of Seven Cases with Delayed Evolution of Symptoms
}

\author{
B.G. BENOIT, N.A. RUSSELL, M.T. RICHARD, H. HUGENHOLTZ, E.C.G. VENTUREYRA, and S.H. CHOO
}

\begin{abstract}
SUMMARY: Epidural hematomas occasionally have a prolonged clinical course with gradual evolution of the neurologic symptoms. Seven such cases are reviewed in this report. Although the clinical course is insidious, there are certain features which should signal the presence of a slowly expanding hematoma. After an apparently minor head injury, the patient who is usually in the younger age group, develops headache. This persists and is accompanied by other non-specific neurologic symptoms which may lead to a mistaken diagnosis of "post-concussion syndrome". Papilledema and focal neurologic deficits eventually appear. Definitive diagnosis is made by the CT scan, although contrast enhancement may be necessary to confirm the nature of the lesion. The treatment is craniotomy and evacuation of the hematoma before serious neurologic deterioration occurs.
\end{abstract}

RÉSUMÉ: Il est possible de voir des hématomes épiduraux dont l'évolution est prolongée, particulièrement en ce qui concerne l'apparition des signes neurologiques. Nous présentons sept cas de ce genre. Même devant une évolution insidieuse, il existe des signes annonçant la présence d'un hématome en croissance lente. Après un traumatisme crânien de faible importance, le patient généralement jeune développe des céphalées. La persistance de ce symptôme accompagné conduit souvent au diagnostic erroné de syndrome postcommotion. Eventuellement le papilloedème et les signes localisés apparaissent. Le diagnostic définitif est fait par tomodensitométrie, souvent avec contraste. Le traitement se fait par crâniotomie et l'éva. cuation de l'hématome avant la détérioration neurologique.

From the Divisions of Neurosurgery, Ottawa Civic Hospital, Ottawa General Hospital, Children's Hospital of Eastern Ontario and University of Ottawa.

Requests for reprints to: Brien G. Benoit, M.D., F.R.C.S.(C), F.A.C.S. Suite 308, 1081 Carling Avenue, Ottawa, Ontario K1 Y 4G2

\section{INTRODUCTION}

The classical epidural hematoma is a rapidly expanding intracranial mass which produces progressive neurologic deterioration, usually within 12 hours of injury. The rarer "chronic" variety is less well defined. In these, the hematoma enlarges slowly, so that days or weeks may pass before it becomes apparent. This paper reviews our experience with seven such cases. It illustrates the features of a potentially lethal condition, which often presents significant diagnostic difficulty.

\section{CASE REPORTS}

Case 1: A 16 year old male, wearing a helmet, was struck in the left temporal region by a hockey puck. There was momentary loss of consciousness. Twenty-four hours later he complained of headache and drowsiness. These symptoms persisted over the next three days. Mild dysphasia and early papilledema were discovered on repeat examination. Skull $x$-rays demonstrated a linear left temporo-parietal fracture. A provisional diagnosis of cerebral contusion was made and dexamethasone therapy was started. One week later he had not improved and an upper motor neuron right facial palsy developed. Carotid angiography revealed an extracerebral left-sided hematoma. At craniotomy, 14 days after injury, an organized epidural hematoma was removed from the left temporo-parietal region. The source of bleeding was not discovered. Recovery was complete and uneventful.

Case 2: A 19 year old male, wearing a helmet, was struck in the head at an undetermined site, by a hockey puck. There was no loss of consciousness. Skull $\mathrm{x}$-rays were negative. Two days later he developed persistent headache and nausea. Fifteen days later examination showed bilateral papilledema but no other abnormalities. A right- sided extra cerebral hematoma was demonstrated by carotid angiography. A craniotomy was performed 21 days after injury and a chronic epidural hematoma removed from the right middle cranial fossa. It was well organized, densely adherent to the dura and covered by a membrane. There was no active bleeding. Recovery was uneventful.

Case 3: A 20 year old male fell from a roof and was momentarily unconscious. Skull $\mathrm{x}$-rays revealed a right linear parietal fracture. He was admitted to hospital where no abnormalities were noted apart from mild drowsiness. After five days, he was discharged.

$\mathrm{He}$ developed headache and began to complain of double vision. At reassessment, approximately six weeks later, early papilledema was discovered. There were no other abnormalities. A CT scan revealed an isodense bi-convex extra cerebral mass in the right temporal region. There was a well defined inner "rim" on nonenhanced views (Fig. 1). A craniotomy was performed 46 days after the injury and a well organized epidural hematoma was removed from the right middle fossa. There were vascular inner and outer membranes enclosing semigelatinous material. No source of bleeding was noted. Recovery was rapid and complete.

Case 4: A six year old female fell from a bicycle striking her chin. There was no loss of consciousness. Skull $x$-rays were reported as negative. Two days later, because of drowsiness and vomiting she was admitted to hospital. Examination revealed her to be drowsy and irritable but without focal neurologic deficit. Repeat skull $x$-rays were negative, but $x$-rays of the facial bones showed a fracture-dislocation of the right temporo-mandibular joint. Two days later a mild left hemiparesis with an extensor plantar response was 


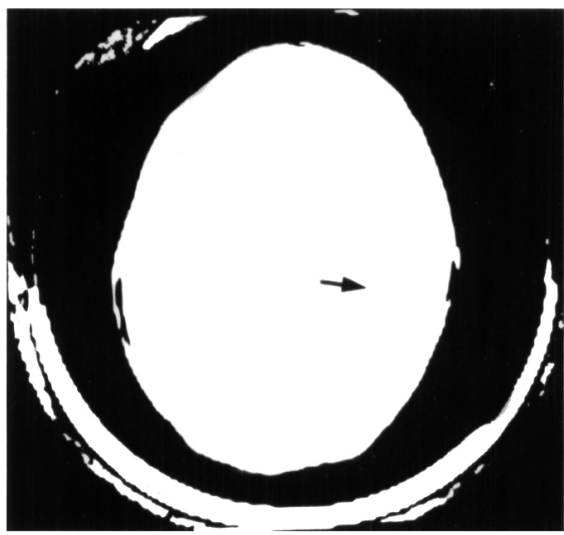

Figure 1 - Case 3 - Inner "Rim" of Increased Density Representing Membrane of Chronic Epidural Hematoma.

noted. Early papilledema was present. An unenhanced CT scan revealed an extra cerebral bi-convex density in the right temporo-parietal region, which was thought to be a subdural hematoma. At craniotomy, 14 days after injury, a well organized right temporoparietal epidural hematoma was removed. No source of bleeding was found. Recovery was uneventful.

Case 5: A 12 year old female fell from a bicycle striking her head. There was an immediate generalized convulsion. On admission to hospital shortly afterwards, she was unconscious, with conjugate deviation of her eyes to the right but stable vital signs. Skull $x$-rays showed a linear right temporal fracture and a diastasis of the temporo-parietal suture. A provisional diagnosis of cerebral contusion and post-ictal state was made. Dexamethasone and phenytoin therapy was begun and an unenhanced CT scan was performed. An area of increased density in the right temporal region was considered to confirm the clinical impression of cerebral contusion. Her clinical status rapidly improved so that after several hours she was alert and fully oriented. Eight days after admission, she complained of headache and early papilledema was discovered. Another unenhanced CT scan showed a right temporo-parietal extra cerebral hematoma. At craniotomy, 14 days after her injury, a well organized epidural hematoma was removed. No bleeding source was found. Recovery was rapid and complete.
Case 6: A 24 year old male was struck in the left temporal region by the end of a T-bar ski tow. He did not lose consciousness, and was able to ski down the hill without difficulty. Approximately 20 minutes following the injury, he had a generalized convulsion. He was admitted to hospital where he rapidly regained consciousness and no neurologic abnormalities were noted. Approximately 24 hours later, he complained of severe headache. Over the following two days the headache continued. On examination, he was mildly drowsy. He complained of severe headache and was dsyphasic. There was slight incoordination of his right arm and leg. Papilledema was not present. Skull x-rays revealed no fracture. An unenhanced CT scan showed a biconvex extra cerebral mass situated low in the left middle fossa. A craniotomy was performed four days after the injury and an organized epidural hematoma removed. No bleeding source was found. Recovery was rapid and complete.

Case 7: A 16 year old male was knocked down by a car. He had an immediate generalized convulsion. On examination shortly afterwards, he was vocalizing, but stuporous and extremely irritable. There was a painful swelling over the left occipit. Plantar responses were bilaterally extensor. Skull $x$-rays were negative. Dexamethasone and phenytoin were given. $\mathrm{He}$ rapidly improved and was discharged from hospital without neurologic abnormality five days later. Twenty-four hours later, he was brought back to hospital because of a behavior change. On examination, he was confused and disoriented. Bilateral extensor plantar responses and early papilledema were noted. An unenhanced CT scan showed a bi-convex extra cerebral lesion in the left temporo-parietal region. A craniotomy was performed eight days after the injury and an organized epidural hematoma was removed. No active bleeding was found. His improvement was rapid so that he was discharged asymptomatic eight days later.

\section{ANALYSIS}

The main features of these cases are summarized in Table I. Of the seven cases, five were male and two female. The age ranged from 6 to 24 years, the average being 16 . Two were injured by hockey pucks while wearing conventional helmets and one was struck by the relatively sharp end of a T-bar ski tow; three others were injured in falls, one from a height and two from bicycles. The other was struck by an automobile.

Three patients had no initial loss of consciousness; two were momentarily unconscious, but had no significant amnesia. Two patients had seizures immediately after the injury and one, who was not initially unconscious, had a seizure 20 minutes later. Six developed headache as a prominent feature of the subsequent symptoms. Four had associated drowsiness and impaired memory. Five developed focal neurologic deficits and six papilledema.

The diagnosis was made by carotid angiography in two (pre CT era) and in the other five by CT scan. The interval from injury to surgery ranged from 4 to 46 days with an average of 17.2 days.

All the hematomas were located in the temporal or temporo-parietal regions and all were organized. Membrane formation was noted in two; one had an outer membrane only, and the other had well defined inner and outer membranes with liquefaction of the clot.

\section{DISCUSSION}

Epidural hematomas have been classified as subacute or chronic when the clinical manifestations are delayed so that the interval from injury to operation is more than 24-48 hours. (Sparacio et al, 1972; Pozzati et al, 1980). The literature emphasizes the insidious nature of the symptoms, but the clinical picture is typical (King et al, 1952; Iwakuma and Brunngraber, 1973; Heiskanen, 1975; Pozzati et al, 1980 ). A child or young adult suffers what appears to be a trivial head injury, often causing no loss of consciousness. Subsequently a persistent headache develops, which may be accompanied by nausea, vomiting, impairment of thought and memory, drowsiness and diplopia. These symptoms usually lead to a diagnosis of "post-concussion syndrome". As time passes, focal neurologic signs and 
papilledema appear. Skull radiographs usually, but not invariably, reveal a linear fracture. (Mealey, 1960; Hawkes and Ogle, 1962; Pozzati et al, 1980).

CT scanning is the investigation of choice. In an acute epidural hematoma, it shows an extra axial bi-concave lesion of blood density. This has a sharp inner margin and is well localized, because the attachment of the dura mater to the inner table of the skull does not allow the bleeding to spread. The features of the more slowly evolving hematomas are less clearly defined. Allen (1977) and Omar and Binet (1978) described non-contrast enhanced scans in several patients with these lesions. In all, an inner "rim" of increased density was noted between the hematoma and the compressed brain and intravenous injection of contrast medium resulted in enhancement of the "rim". Case 3 in our series (Fig. 1) exhibited this phenomenon which is thought to represent compressed dura covered by vascular granulation tissue.

Handa et al (1979) reported three cases of delayed epidural hematoma, in which the diagnosis was confirmed only by a contrast enhanced CT scan. In two, the hematomas were isodense and their extra axial location could not be recognized. After the intravenous injection of contrast medium, there was clear enhancement of the inner "rim" and the bi-convex extra axial mass was easily identified. Similar cases have since been described (Burres and Hamilton, 1979; Hirsch, 1980; Davis and Nichols, 1980).

High pressure hemorrhage from a torn middle meningeal artery is the usual cause of an acute epidural hematoma. The clot accumulates quickly and causes early medial uncal displacement. Chronic hematomas probably arise from low tension sources of bleeding, i.e. venous, dural or diploic (Munroe and Maltby, 1941; I wakuma and Brunngraber, 1973; Pozzati, 1980). The hemorrhage is slower, allowing time for the intracranial contents to accommodate to the mass. The higher incidence in youth has been at-

TABLE I

Synopsis of seven cases of epidural hematoma with delayed onset of symptoms.

\begin{tabular}{|c|c|c|c|c|c|c|c|}
\hline \multirow{2}{*}{ Case } & \multicolumn{2}{|c|}{$\begin{array}{l}\text { Mechanism } \\
\text { Age/Sex of Injury }\end{array}$} & \multirow[t]{2}{*}{$\begin{array}{l}\text { Linear } \\
\text { Skull } \\
\text { Fracture }\end{array}$} & \multirow{2}{*}{$\begin{array}{l}\text { Clinical Course } \\
\text { Momentary loss of conscious- } \\
\text { ness. Headache and drowsiness } \\
24 \text { hours later. Subsequently } \\
\text { dysphasia, papilledema and } \\
\text { upper-motor neuron right } \\
\text { facial nerve palsy. }\end{array}$} & \multicolumn{2}{|c|}{$\begin{array}{cc}\text { Injury-S } \\
\text { Interval } \\
\text { Investigations (Days) }\end{array}$} & \multirow{2}{*}{$\begin{array}{l}\text { gery } \\
\text { Operative Findings } \\
\text { Organized left } \\
\text { temporo-parietal } \\
\text { epidural hematoma. }\end{array}$} \\
\hline & $16 / \mathrm{M}$ & $\begin{array}{l}\text { Struck by } \\
\text { hockey } \\
\text { puck. }\end{array}$ & & & $\begin{array}{l}\text { Carotid } \\
\text { angiography }\end{array}$ & 14 & \\
\hline 2 & $19 / \mathrm{M}$ & $\begin{array}{l}\text { Struck by } \\
\text { hockey } \\
\text { puck. }\end{array}$ & No & $\begin{array}{l}\text { No loss of consciousness. } \\
\text { Headache and nausea } 2 \text { days } \\
\text { later. Papilledema at } 15 \\
\text { days. }\end{array}$ & $\begin{array}{l}\text { Carotid } \\
\text { angiography }\end{array}$ & 21 & $\begin{array}{l}\text { Organized right } \\
\text { middle fossa epidural } \\
\text { hematoma with outer } \\
\text { membrane. }\end{array}$ \\
\hline 3 & $20 / \mathrm{M}$ & $\begin{array}{l}\text { Fall from } \\
\text { height. }\end{array}$ & Yes & $\begin{array}{l}\text { Momentary loss of conscious- } \\
\text { ness. Headache and double } \\
\text { vision after } 5 \text { days. Pap- } \\
\text { illedema } 6 \text { weeks later. }\end{array}$ & CT scan & 46 & $\begin{array}{l}\text { Well organized } \\
\text { right middle fossa } \\
\text { epidural hematoma with } \\
\text { inner and outer membranes. }\end{array}$ \\
\hline 4 & $6 / F$ & $\begin{array}{l}\text { Fall from } \\
\text { bicycle. }\end{array}$ & No & $\begin{array}{l}\text { No loss of consciousness. } \\
\text { Headache, drowsiness and } \\
\text { vomiting } 2 \text { days later. Sub- } \\
\text { sequently left hemiparesis } \\
\text { and papilledema. }\end{array}$ & $\begin{array}{l}\text { CT scan and } \\
\text { carotid } \\
\text { angiography }\end{array}$ & 14 & $\begin{array}{l}\text { Organized right } \\
\text { temporo-parietal } \\
\text { epidural hematoma. }\end{array}$ \\
\hline 5 & $12 / F$ & $\begin{array}{l}\text { Fall from } \\
\text { bicycle. }\end{array}$ & Yes & $\begin{array}{l}\text { Immediate seizure. Recovery } \\
\text { within several hours. Head- } \\
\text { ache began } 8 \text { days later. } \\
\text { Papilledema noted. }\end{array}$ & CT scan & 14 & $\begin{array}{l}\text { Organized right } \\
\text { temporo-parietal } \\
\text { epidural hematoma. }\end{array}$ \\
\hline 6 & $24 / \mathrm{M}$ & $\begin{array}{l}\text { Struck by } \\
\text { ski T-bar } \\
\text { tow. }\end{array}$ & No & $\begin{array}{l}\text { No loss of consciousness. } \\
\text { Seizure } 20 \text { min. later with } \\
\text { full recovery. After } 24 \text { hrs. } \\
\text { persistant headache, drowsi- } \\
\text { ness and dysphasia. Right } \\
\text { hemiparesis } 2 \text { days later. }\end{array}$ & CT scan & 4 & $\begin{array}{l}\text { Organized left } \\
\text { middle fossa epidural } \\
\text { hematoma. }\end{array}$ \\
\hline 7 & $16 / \mathrm{M}$ & $\begin{array}{l}\text { Struck by } \\
\text { car. }\end{array}$ & No & $\begin{array}{l}\text { Immediate seizure with } \\
\text { rapid recovery. Six days } \\
\text { later became confused and } \\
\text { disoriented with extensor } \\
\text { plantars and papilledema. }\end{array}$ & CT scan & 8 & $\begin{array}{l}\text { Organized left } \\
\text { temporo-parietal } \\
\text { epidural hematoma. }\end{array}$ \\
\hline
\end{tabular}


tributed to the dura being less adherent; it can thus be separated from the inner table of the skull by a blow which causes deformation, but not necessarily fracture (Hooper, 1959).

It is generally stated that most subacute and chronic epidural hematomas occur outside the temporal region (Jamieson and Yelland, 1968; McLaurin and Ford, 1964; Hirsch, 1980). Our own experience, and that of others (Pozzati et al, 1980) is different; in each of our patients, the hematoma arose in the middle cranial fossa. It is also generaliy believed that chronic epidural hematomas do not undergo the process of membrane formation and the liquefaction that is so common with their subdural counterparts (Sparacio et al, 1972). However, Iwakuma and Brunngraber (1973) found encapsulated hematomas in two of their patients. They suggested that membrane formation was time related and that a period of approximately five weeks was necessary for its formation. Two of our patients had membranes. In Case 2, where the interval from injury to surgery was 21 days, there was an outer membrane; in Case 3 , where the interval was 46 days, there were well formed inner and outer membranes and beginning liquefaction of the clot.

Burres and Hamilton (1979) ques- tioned the necessity of surgery in all chronic epidural hematomas, suggesting that some may spontaneously absorb. This is reasonable if the hematoma demonstrated by CT scanning is a "thin film", but any sizable mass should be promptly removed. Although the evolution is indolent, these hematomas have a potential for continued expansion. If this is allowed to continue a time will be reached when accommodation of the intracranial contents will give way leading to the same disasterous result that occurs with acute epidural hematoma.

\section{REFERENCES}

ALLEN, J.R. (1975) Computed tomographic scan findings in closed head trauma. Computed Axial Tomography 1:115-120.

BURRES, K.P., HAMILTON, R.D. (1979) Chronic extradural hematoma: Case report. Neurosurg. 4:60-62.

DAVIS, C.H., NICHOLS, R.W.: (1980) Late diagnosis by computerized tomography of unsuspected extradural hematoma (letter). Lancet. 1:416-417.

HANDA, J., HANDA, H., NAKONO, Y. (1979) Rim enhancement in computed tomography with chronic epidural hematoma. Surg. Neurol. 11:217-220.

HAWKES, C.D., OGLE, W.S. (1962) Atypical features of epidural hematoma in infants, children, and adolescents. J. Neurosurg. 19:971-980.
HEISKANEN, O. (1975) Epidural hematoma. Surg. Neurol. 4:23-26.

HIRSCH, L.F. (1980) Chronic epidural hematomas. Neurosurg. 6:508-512.

HOOPER, R. (1959) Observations on extradural hemorrhage. Brit. J. Surg. 47:71-87.

IWAKUMA, T., BRUNNGRABER, C.V. (1973) Chronic extradural hematomas: A study of 21 cases. J. Neurosurg. 38:488-493.

JAMIESON, R.G., YELLAND, J.D. (1968) Extradural hematoma: Report of 167 cases. J. Neurosurg. 29:13-23.

KING, A.B., CHAMBERS, J.W. (1952) Delayed onset of symptoms due to extradural hematomas. Surg. 31:839-844.

MEALEY, J. (1960) Acute extradural hematomas without demonstrable skull fractures. J. Neurosurg. 17:27-34.

McLAURIN, R.L., FORD, L.E. (1964) Extradural hematomas. J. Neurosurg. 21:364371.

MUNRO, D., MALTBY, G.L. (1941) “Extradural Hemorrhage; A Study of 44 Cases". Ann. Surg. 113; 192-203.

OMAR, M.M., BINET, E.F. (1978) Peripheral contrast enhancement in chronic epidural hematomas. J. Comput. Assist. Tomog. 2:332-335.

POZZATI, E., FRANCO, F., FRANK, G., GAIST, G. (1980) Subacute and chronic extradural hematomas: A study of 30 cases. J. Trauma 20:795-799.

SPARACIO, R.R., KHATIB, R., CHIU, J., COOK, A.W. (1972) Chronic epidural hematoma. J. Trauma 12:435-439. 